\title{
Impact of Fungi/ Nematode Interactions on Food Crops in Nigeria
}

\author{
D. N. Aghale, ${ }^{1 *}$ O. J. Umeh ${ }^{2}$, Nzeako, F.C ${ }^{2}$ \\ ${ }^{1 .}$ Department of Plant Science and Biotechnology. Michael Okpara University of Agriculture, Umudike, Nigeria \\ 2. Department of Rural Sociology and Extension. Michael Okpara University of Agriculture, Umudike, Nigeria
}

*Corresponding Author: D. N. Aghale, Department of Plant Science and Biotechnology. Michael Okpara University of Agriculture, Umudike, Nigeria

\begin{abstract}
This review centers on the role of nematode and fungi in plant diseases and their interactions on disease complex. Fungi attack plants at all stages of its development resulting into rust, mildew, leaf spot and chlorosis that led to the death of its host while nematodes reduce plant growth and yield efficiency due to their feeding habit on host plants.Parasitic nematodes causes wounds to their host plant either by simple micro - puncture or by rupturing on the roots and is important in predisposing plants to fungi infection through the creation of more infection sites. Nematode attacks lowers the resistances of plants to diseases caused by other organism and create new plant pathogenic fungi with an increase in the pathogenicity of other microorganisms. The role of fungi is related to the behavior of fungal pathogens in a dormant or active state under changed conditions created through infection of the host plant by parasitic nematode. Fungi / nematode interaction in disease complex results into major consequences in increased early plant mortality in the growing season and also resistance to fusarium wilt symptoms were more severe, developed more rapidly with greater frequency when infected by nematode. The role of fungi in the interactions with nematode is not delineation because a synergistic relationship, the common feature of fungus / nematode interaction and diseases caused by fungal pathogen become more pronounced and may appear earlier when plants are infected with nematodes.
\end{abstract}

Keywords: Fungi, Nematode, interactions and disease complex

\section{INTRODUCTION}

Fungi are eukaryotic organisms that lack chlorophyll and do not have the ability to photosynthesize their own food. They obtain nutrient by absorption through tiny thread like filaments called hyphae that branch in all directions throughout a substrate. A collection of these hyphae referred to as mycelium is the diagnostic sign associated with diseases caused by fungi.Fungi attack almost all higher plants either in their roots, stems, leaves, fruits, or seeds and reduce the viability, germination potentials of seeds, destroy seedlings, damage whole plant at any stage during its life cycle and even attack harvested products in storage. There are many different fungi that are capable of causing diseases on plants with the attendant signs and symptoms such as leaf rust, stem rust and powdering mildew while some of the symptoms are damping off, leaf spot and chlorosis. Pathogenic fungi penetrate the plant either by making holes on the epidermis or by growing through the production of specialized hyphae structures called appresoria on the host plant, poison and kill the plant cells before absorbing food from them. The spores of some fungi come through the air and infect the plant parts which also may block the water conducting cells or kill them, thus causing the plant to wilt resulting unto death. Some of thePathogenic fungi which threaten the crop plants are phytophthorainfestans that causes late blight of potato, and pucciniagraministritici that causes wheat rust.

Nematodes on the other hand, reduce plant growth and yield efficiency due to their feeding habit on the roots, tubers, bulbs and corms while majority of them feed on fungi and bacteria in the soil and are in turn preyed upon. Plant parasitic nematodes of economic importance are grouped into relatively restricted specialized sections that either cause direct damage to their feed host or act as fungi vectors. The feeding of nematodes among other damages facilitates subsequent infestation by secondary 
pathogens such as fungi and bacteria (Powell, 1971). The effect of nematode feeding on plants range from simple mechanical injury through plant cells to complex host parasitic interaction. These host interactions involve physiological changes in host tissues as a result of excreted substances by the nematode and synergist relationship between fungi and nematodes that increase the severity of plant diseases. In nematode fungus plant interactions, the role of nematode is more complex than simple wounding, since wounds are not required for infection of plants by fungi when involved. Infections by some nematodes have been reported to increase the death and non- susceptible crop plant becomes susceptible in the presence of nematode. Thus the review on the impact of fungi/ nematode interaction on disease complex management in food crops for increase sustainable production in Nigeria.

\section{OBJECTIVES}

To Review nematode as wound agents on major food crops in Nigeria.

Role of fungal as a major pathogen infood crop production

Effect of fungi/ nematode interaction on food crops.

\section{Nematode as wound agents on major food crops in Nigeria}

All plant parasitic nematodes causes wounds to their host plant either by simple micro - puncture or by rupturing on the roots. And in this process, they may either introduce the fungi pathogen or aid the fungi already present on the crop plant surfaces. Potato cyst nematodes not only cause wounds to the root but also provide entry sites for fungi and other microorganisms which results in great yield loss especially in the presence of the fungus Verticilliumdahiliae in the soil ( Storey\& Evans, 1987). There has been report on reduced root weight when compared with uninfected plants as a result of galling and mechanical damage of roots by nematode which facilitated the entry and development of secondary pathogen like fungi and bacteria. In yam, root knot nematode penetrate the tubers up to $15 \mathrm{~mm}$ from the peridermal surface and the holes created on the tubers pre-dispose the yam for further invasion by fungi and other phytopathogens, thus increasing the rate of biodeterioation of tubers at storage ( Nwauzor, et al., 1990).Scutellonemabradys predisposes yam tubers to infection by Aspergillusniger which is incapable of self-infection establishment (Adesiyan, 1980). Nematodes are considered as primary pathogen in yam tuber deterioration because they cause decay of the tissues and make the infected tuber more prone to fungal attack. Radopholussimilisaids black head toppling disease of banana while Pratylenechuspenetrans infection on eggplant results into Verticillumalboatrum proliferation in the plant roots more readily than in its absence. $R$. similis nematode is the primary cause of spreading decline in citrus, and pathogenic fungi like fusarium are commonly found in lesion soon after the nematode invasion, while fungi such as Penicillium andAspergillus invade the roots causing additional destruction.

Nematode is important in predisposing plants tofungi infection through the creation of more infection sites and by changing the host physiology, biochemical constituent for better and nutritious substrate growth of the fungi. In most cases, fungi disease may not develop fully without the nematodes. Adesiyan (2000) reported that nematodes such as Meloidogyne, Radopholus, Heterodera, Pratylenchus, andRotylenchusassisted fungi like Fusarium,Verticillum, Phytophora and Rhizoctonia in diseases on plant parts.

\section{Role of fungal as a major pathogen in food crop production}

Fungi are disease causing agents of rot in yam, potato and cassava with varying symptoms as in coloration. Fungal invasion of root and tuber crops are considered as the most critical factor in rot (Degras, 1993). In soft rot, the infected tissue become soft ramified by the fungi mycelium which turn brown and wet due to a rapid collapse of the cell wall (IITA, 1993). Fungi associated with this action include Rhizopusspp, Mucorcircinelloide and Armillariellamoltea(Greenet al., 1995). Fungi pathogens produce various mycotoxins on the crop products like oil seeds, maize, legumes and cereals while the agricultural important mycotoxins areaflatoxins, funonisins, ochratoxins and deoxyinivanelol( Bankoleet al., 2013). Fungi toxins contamination of food crop products causes acute or chronic intoxication leading to reduce shelf life. Fungi diseases such as the corn smut caused by Ustilagomaydis which are usually seed borne and then become systemic, causing hypertrophy on fruiting only when the next generation of seeds are produced thus, taking away the concentrated energy stored by the plant for its own reproduction. Others are anthracnose (tissue necrosis) in beans caused by colletotrichum, coffee rust disease resulting into leaf abscission and caused 
byHemileavastatrix. Botrytis cinerea has an impact due to its broad host range, causing severe damage to both pre and post-harvest. Puccinaspp is a serious disease threat but have increased in impact with the emergence of a new race which is posing a serious challenge to wheat production. Fusariumoxysporum have a wide host range with severe losses in crops as diverse as tomato, cotton and banana. Wheat crops were commonly destroyed when the grains become infected with a dark, dusty powder known to be the spore of the fungus called bunt or stinking smut Tilletia spp. The potato blight was caused by the fungal- like organism (phytophthorainfestans) which was named by Anton de Bary in 1876 as plant destroyer. The grape vine disease caused by plasmoperaviticoleresults into serious losses in grape yield. Thus, fungi have been identified as a major pathogen militating against food production in agricultural enterprises.

\section{Effect of fungi/ Nematode interaction on food crops}

The soil environment is favorable for the activities of pathogenic fungi and other plant parasitic nematodes hence variety of disease development in food crops have been known to depend on the complex interrelationship between the host, pathogen and prevailing environmental conditions. These disease complexes produced through a synergistic interaction between two organisms are referred to as being positive if it results into plant damage that exceeded the sum of individual damage by the pathogen. An association between fungi / nematode resulting into damage that is less than expected from the sum of the individual organisms is referred to as antagonistic interactions, whereas fungi/ nematode interactions resulting into damage that is equal to the sum of individual pathogen damage is known as neutral interactions. Nematodes / fungus disease complexes involve root knot nematodes (Meloidogyne species), and several other endoparasitic nematodeslike (Globoderaspp, Heteroderaspp, Rotylenechulus, pratylenechus) and ectoparasitic( Xiphnemaspp, longidorus) have been associated with diseases caused by fungal pathogen. Evans\&Haydock, (1993) reviewed nematode/ fungus complexes previously and discuss on the mechanism underlying synergistic interactions. Abd-ElAlimet al., (1999) reported on nematode- fungus interaction betweenfusarium wilt of cotton caused by fusariumoxysporum which was more severe in the presence of root knot nematode (Meloidogynespp). Interactions between nematode and fungi pathogen has been reported in banana (Jonathan and Rajend 1998), coffee (Bertrend, et al., 2000) and tomatoes, (Sulemanet al., 1997). Nematodes such as Xiphinema(Dagger) and Longidorus (needle) has been identified as important vectors of plant parasitic fungi and Walker et al., (1998) reported on the association betweenMeloidogyne incognita and Thielaviopsisbasicola which causes black rot of cotton. Thus neither of these organisms could result in acute effect individually and plant mortality rarely occurs in their presence, yet in combination they consistently increase seedling mortality, increase root necrosis, suppress early seedling growth and subsequently reduce the percentage of bolls.

Globodera /Verticilliumdahlia and Pratylenchus /vertillium dahlia disease complex have resulted into early senescence or early death. However, the fundamental importance of $P$. penetransin potato early dying is its ability to activate low population of $V$. dahlia that would otherwise be in consequential in disease development (Brown et al., 1996). The soybeans Cyst nematode Heterodera glycine and fungus Fusariumsolani causes sudden death syndrome (SDS) by F.solaniis a major disease of soybeans under the presence of nematode that results into root rot, crown necrosis, interveinalchlorosis, defoliation and abortion of pods (Naka Jima et al., 1996).

Botseas and Rowe, (1994) reported on $V$. dahliae - Pratylenchus complex of potato and the interaction between these organisms varies among different nematode species, population as well as fungal genotypes. The wilt fungus is dependent on the timing of invasion by the cyst nematode Globoderapallidaand also on the potato cultivar. The association between fungal pathogen and the injuries caused to plants by nematodes was reported by Polychronopoulos et al., (1969) and the invasion process of Heteroderaschachtii facilitates the interaction of sugar beet by the damping off fungus (Rhizoctoriasolani) that results into early senescence. Powell (1971) reported that Trichderma, Curvularia, Botrytis, Aspergillus and Peniclium are fungi which ordinarily cannot establish a parasitic relationship on plants but when the plant has been predisposed by root knot nematodes they all cause major diseases.

\section{CONCLUSION}

The role of fungi is related to the behavior of fungal pathogens in a dormant or active state under changed conditions created through infection of the host plant parasitic nematode. 
Fungi/ nematode interaction in disease complex results into major consequences in increased early plant mortality in the growing season and also resistance to fusarium wilt symptoms were more severe, developed more rapidly with greater frequency when infected by nematode. The role of fungi in the interactions with nematode is not delineation because a synergistic relationship, the common feature of fungus / nematode interaction and diseases caused by fungal pathogen become more pronounced and may appear earlier when plants are infected with nematodes. Some soil fungi which are normally known to be non-parasitic on roots infect with nematode will generally, in synergistic interaction with the nematodes provide an opportunity for fungal pathogen in showing greater pathogenic capabilities. The behavior of fungi in nematode infected roots becomes more aggressive its capabilities also increased in plant roots infected with fungi.

The development of diseases in cultivated crops has been known to depend on the complex interrelationship between host, pathogen and prevailing environmental conditions. In soil borne pathogens, opportunities exist for interactions with other microorganisms occupying the same ecological niche. The significant role of nematode in the development of diseases caused by fungi has been reviewed in this work.

\section{REFERENCES}

Abd-El-Alim FF, Barker KR, Ibrahim IK, Darwish AK, Michail SH, (1999).Interactions of Fusariumoxysporumf.sp.vasinfectum and Meloidogyne incognita on selected cotton genotypes. Pakistan Journal of Nematology17, 51-60.

Adesiyan, S.O.,F.ECavenss., M.O Adeniji., B. Fawole (2000). In Nematode pests of Tropical crops. Pp3.

Adesiyan, S.(1980). The interrelationships of Scutellonemabradys and Aspergillusnigeron tuber formation and the dry rot disease of water yam. Nigerian Journal of Agric. Sciences, (2). 49-52.

Bankole, S.A and Adebanjo, A. (2003).Mycotoxins in food in West Africa. Current situation and possibility of controlling it. African Journal of Biotechnology, 2(9).254-263.

Bertrand B, Nunez C, Sarah J.L, (2000). Disease complex in coffee involving Meloidogynearabicida and Fusariumoxysporum.Plant Pathology49, 383-8.

Botseas DD, Rowe RC, (1994). Development of potato early dying in response to infection by twopathotypes of Verticilliumdahliae and coinfection by Pratylenchuspenetrans.

Phytopathology $84,275-82$.

Bowers JH, Nameth ST, Riedel RM, Rowe RC, (1996). Infection and colonisation of potato roots by Verticilliumdahliae as affected by Pratylenchuspenetrans and $P$. crenatus.Phytopathology86, 614-21.

Degras, L. (1993). The yam (A tropical root crop). Macmillan Press, London. Pp. 408.

Evans K, Haydock PPJ, (1993). Interactions of nematodes with root-rot fungi. In: WajidKhanM, ed. Nematode Interactions. London, UK: Chapman \& Hall, 104-33.

Green, K.R and D.A Florini, (1995).Pest and pathogen of yam in storage. A meeting report. African Journal of Root and Tuber Crops.1(2) 38-42.

IITA, (1993).(International Institute of Tropical Agriculture, Annual report. Ibadan, Nigeria. 208p

Jonathan EI, Rajendran G, (1998). Interaction of Meloidogyne incognita and Fusarium oxysporumf.sp. cubense on banana. NematologiaMediterranea26, 9-12

Nakajima T, Mitsueda T, Charchar MJD, (1996). First occurrence of sudden death syndrome of soybean in Brazil.Japan Agricultural Research Quarterly30, 31-4.

Nwauzor, E.C and B. Fawole, (1990). Penetration and survival of root knot nematode in stored yam tuber. Nig. J. pl. protection. Vol. 13, 60-65.

Polychronopoulos AG, Houston BR, Lownsbery BF, (1969).Penetration and development of Rhizoctoniasolani in sugar beet seedlings infected with Heteroderaschachtii. Phytopathology59, 482-5.

Powell NT, (1971). Interactions between nematodes and fungi in disease complexes. Annual

Review of Phytopathology 9, 253-74.

Storey GW, Evans K, (1987).Interactions between Globoderapallida juveniles, Verticillium dahliae and three potato cultivars, with descriptions of associated histopathologies. Plant Pathology36, 192-200.

Suleman P, Sardanelli S, Krusberg LR, Straney DC, (1997).Variability among Fusariumoxysporumf.sp. lycopersici isolates in their ability to interact with Meloidogyne incognita race 1. Kuwait Journal of Science and Engineering24, 299-307.

Walker NR, Kirkpatrick TL, Rothrock CS, (1998).Interaction between Meloidogyne incognita and Thielaviopsisbasicola on cotton (Gossypiumhirsutum).Journal of Nematology30, 415-22. 
Citation: D. N. Aghale et al. , " Impact of Fungi/ Nematode Interactions on Food Crops in Nigeria ", International Journal of Advanced Research in Botany, vol. 3, no. 4, p. 1-5, 2017. http://dx.doi.org/10.20431/2455-4316.0304001

Copyright: (C) 2017 Authors. This is an open-access article distributed under the terms of the Creative Commons Attribution License, which permits unrestricted use, distribution, and reproduction in any medium, provided the original author and source are credited. 